Article

\title{
Comparison of gE/gI- and TK/gE/gI-Gene-Deleted Pseudorabies Virus Vaccines Mediated by CRISPR/Cas9 and Cre/Lox Systems
}

\author{
Jianglong Li ${ }^{1,2, \dagger}$, Kui Fang ${ }^{1,2, \dagger}$, Zhenxiang Rong ${ }^{1,2}$, Xinxin Li ${ }^{1,2}$, Xujiao Ren ${ }^{1,2}$, Hui Ma ${ }^{1,2}$, \\ Huanchun Chen ${ }^{1,2,3}$, Xiangmin Li ${ }^{1,2,3, *}$ and Ping Qian 1,2,3,* \\ 1 State Key Laboratory of Agricultural Microbiology, Huazhong Agricultural University, Wuhan 430070, \\ China; LJLHZAU0413@126.com (J.L.); fangkui1987@126.com (K.F.); rzx17806250660@163.com (Z.R.); \\ 1xxhzau@163.com (X.L.); renxujiao92@163.com (X.R.); qiagen@163.com (H.M.); \\ chenhch@mail.hzau.edu.cn (H.C.) \\ 2 Laboratory of Animal Virology, College of Veterinary Medicine, Huazhong Agricultural University, \\ Wuhan 430070, China \\ 3 Key Laboratory of Preventive Veterinary Medicine in Hubei Province, The Cooperative Innovation Center \\ for Sustainable Pig Production, Wuhan 430070, China \\ * Correspondence: lixiangmin@mail.hzau.edu.cn (X.L.); qianpinghzau120@163.com (P.Q.); \\ Tel.: +86-27-87282608 (P.Q.) \\ + These authors contributed equally to this work.
}

Received: 28 January 2020; Accepted: 22 March 2020; Published: 27 March 2020

check for updates

\begin{abstract}
Pseudorabies (PR), caused by pseudorabies virus (PRV), is an acute and febrile infectious disease in swine. To eradicate PR, a more efficacious vaccine needs to be developed. Here, the gE/gIand TK/gE/gI-gene-deleted recombinant PRV (rGX $\Delta \mathrm{gE} / \mathrm{gI}$ and $\mathrm{rGX} \Delta \mathrm{TK} / \mathrm{gE} / \mathrm{gI}$ ) are constructed through CRISPR/Cas9 and Cre/Lox systems. We found that the rGX $\Delta \mathrm{TK} / \mathrm{gE} / \mathrm{gI}$ was safer than $\mathrm{rGX} \Delta \mathrm{gE} / \mathrm{gI}$ in mice. Additionally, the effects of $\mathrm{rGX} \Delta \mathrm{gE} / \mathrm{gI}$ and $\mathrm{rGX} \Delta \mathrm{TK} / \mathrm{gE} / \mathrm{gI}$ were further evaluated in swine. The $\mathrm{rGX} \Delta \mathrm{gE} / \mathrm{gI}$ and $\mathrm{rGX} \Delta \mathrm{TK} / \mathrm{gE} / \mathrm{gI}$ significantly increased numbers of IFN- $\gamma$-producing CD4+ and CD8+ T-cells in swine, whereas there was no difference between $\mathrm{rGX} \Delta \mathrm{gE} / \mathrm{gI}$ and $\mathrm{rGX} \Delta \mathrm{TK} / \mathrm{gE} / \mathrm{gI}$. Moreover, rGX $\Delta \mathrm{gE} / \mathrm{gI}$ and $\mathrm{rGX} \Delta \mathrm{TK} / \mathrm{gE} / \mathrm{gI}$ promoted a PRV-specific humoral immune response. The PRV-specific humoral immune response induced by $\mathrm{rGX} \Delta \mathrm{gE} / \mathrm{gI}$ was consistent with that caused by $\mathrm{rGX} \Delta \mathrm{TK} / \mathrm{gE} / \mathrm{gI}$. After the challenge, swine vaccinated with $\mathrm{rGX} \Delta \mathrm{gE} / \mathrm{gI}$ and $\mathrm{rGX} \Delta \mathrm{TK} / \mathrm{gE} / \mathrm{gI}$ showed no clinical signs and viral shedding. However, histopathological detection revealed that $\mathrm{rGX} \Delta \mathrm{gE} / \mathrm{gI}$, not $\mathrm{rGX} \Delta \mathrm{TK} / \mathrm{gE} / \mathrm{gI}$, caused pathological lesions in brain and lung tissues. In summary, these results demonstrate that the TK/gE/gI-gene-deleted recombinant PRV was safer compared with $\mathrm{rGX} \Delta \mathrm{gE} / \mathrm{gI}$ in swine. The data imply that the TK/gE/gI-gene-deleted recombinant PRV may be a more efficacious vaccine candidate for the prevention of PR.
\end{abstract}

Keywords: CRISPR/Cas9; Cre/Lox; pseudorabies virus; vaccine

\section{Introduction}

Pseudorabies (PR), also known as Aujeszky's disease (AD), is an acute and febrile infectious disease in swine, and it is caused by pseudorabies virus (PRV) [1,2]. PR is characterized by reproductive failure, neurological disorders, and respiratory ailments in swine [3-5]. The disease can lead to substantial economic costs because of reproductive losses in sows and weight loss in PRV-infected adults in swine farmers [2]. Currently, some strategies based on the DIVA (differentiating infected from vaccinated individuals) vaccination program are applied to the eradication of PR in commercial swine populations [6]. A few developed countries, such as United States [3], several European countries [7], 
and New Zealand [8], have eradicated PR, whereas increased infection frequency and severity have again caused PR in swine and other animals since 2011 in China [9]. Therefore, a more efficacious vaccine is considered as a necessary tool to protect against PRV.

PRV is a member of the Herpesviridae family and consists of approximately $150 \mathrm{~K}$ double-strand DNA genome encoding $\sim 70$ proteins $[3,10]$. PRV genome contains a unique long region (UL) and a unique short region (US). The US region, which is bracketed by inverted repeat sequences, forms two possible PRV genome isomers opposite oriented US regions [3]. Genes, including protein kinase (PK), glycoprotein $\mathrm{G}(\mathrm{gG}), \mathrm{gD}, \mathrm{gI}$, and $\mathrm{gE}$, are located within the US region [11]. Increasing evidence has shown that several proteins are closely related to the virulence of PRV, such as gE, gI, thymidine kinase (TK), and PK [12,13]. The gE is associated with cell fusion, virus diffusion between cells, neurotropism, and virion release. Moreover, $\mathrm{gE}$, as a marker gene, is used to distinguish natural infection from vaccination when the vaccine lacks the $g E$ gene [14]. TK is a viral enzyme to mediate PRV replication and spread in the central nervous system [15]. Up to date, all live PRV vaccine strains have been reported to contain one or more gene deletion [16,17]. Several vaccines based on PRV variants have been reported, such as gE/gI-gene-deleted PRV based on the Tianjin strain, inactivated gE/gI-gene-deleted PRV based on the ZJ01 strain, and TK/gE/gI-gene-deleted PRV based on the PR HN1201 strain [18-20]. Therefore, we further performed a comparison of gE/gI- and TK/gE/gI-gene-deleted PRV.

The clustered regularly interspaced short palindromic repeat (CRISPR)/Cas9 system is a robust and highly efficient tool for gene editing, which precisely manipulates specific genomic loci [21-23]. Previous studies have shown that gene editing in recombinants is found to be efficient and convenient within a short period by transfecting the CRISPR/Cas system [2,22-24]. Additionally, the Cre/lox system is a site-specific recombination system that also applied for gene manipulation [25]. A synaptic complex is formed by the association of two Cre-bound loxP sites [24,26,27]. The strand exchange is catalyzed through a mechanism shared by all of the tyrosine recombinases within the synaptic complex [28]. Therefore, it is interesting that gene-editing technology is used for vaccine development.

In the current study, the gE/gI- and TK/gE/gI-gene-deleted recombinant PRVs (rGX $\Delta \mathrm{gE} / \mathrm{gI}$ and rGX $\Delta \mathrm{TK} / \mathrm{gE} / \mathrm{gI}$ ) were developed using CRISPR/Cas9 and Cre/Lox systems. The effects of gE/gIand TK/gE/gI-gene-deleted PRVs on protection against PRV were investigated in swine. The data indicate that the TK/gE/gI-gene-deleted PRV may be a more potentially effective vector to manufacture virus-vectored vaccines.

\section{Materials and Methods}

\subsection{Viruses and Cells}

The highly virulent PRV variant GX, which was adapted to and plaque-purified in PK-15 cells, was isolated from an affected pig farm in Guangxi, China, in 2016. HEK293T and PK-15 cells were cultured in Dulbecco's modified Eagle's medium (Invitrogen, Carlsbad, CA, USA) containing 10\% heat-inactivated fetal bovine sera (FBS), streptomycin $(100 \mu \mathrm{g} / \mathrm{mL})$, and penicillin $(100 \mathrm{IU} / \mathrm{mL})$ at $37^{\circ} \mathrm{C}$ in $5 \% \mathrm{CO}_{2}$.

\subsection{Plasmid Construction, PCR Amplification and Viral Genomic Preparation}

The sgRNAs were designed according to the online CRISPR Design Tool (https://wwws. blueheronbio.com/external/tools/gRNASrc.jsp), and targeted the gE, gI, and TK gene open reading frames. The sequences of sgRNAs are listed in Table 1. The pX335 plasmid (Add gene, Beijing, China) was digested using the BbsI enzyme (New England Biolabs, Beijing, China), and CRISPR/Cas9 constructs were constructed. The primers (Table 1) were designed to amplify gE, gI, and TK homologous arms from the PRV GX strain using PCR, respectively. The GFP were inserted into the TK position, and mCherry were inserted into the gI and gE positions. The TKhm1-loxP-CMV-GFP-SV40polyA-loxP-TKhm2 and gIhm-loxN-CMV-mCherry-SV40polyA-loxN-gEhm donor templates were constructed by overlapping PCR. PRV genomic DNA was extracted through the TIANamp virus DNA kit (TIANGEN, Beijing 
China). The PCR primer synthesis and DNA sequencing in this study were performed by TsingKe Biotech Co. Ltd. (Beijing, China).

Table 1. Sequences that were used in this study.

\begin{tabular}{|c|c|c|}
\hline Name & Sequences $\left(5^{\prime}-3^{\prime}\right)$ & Application \\
\hline \multirow{2}{*}{ TK HR L arm } & F:AAGCTTCGCCGTGGTCGTCACGCCCATGAAGGTGCG & \multirow{2}{*}{ TK hm1amplification } \\
\hline & R:TTAATTAAGGCGCCGTCGAGGTAGATCCGGAGGATGCG & \\
\hline \multirow{2}{*}{ TK HR R arm } & F:TTAATTAATGCGCCTTCACGTCGGAGATGGGGGTGTGAC & \multirow{2}{*}{ TK hm2amplification } \\
\hline & R:AAGCTTGGTGCCGTTGGGGAAGAGCATCAGGGCCTTG & \\
\hline \multirow{2}{*}{ gI HR L arm } & F:AAGCTTGTGCCCGCGCCGACCTTCCCCCCGCCCGCG & \multirow{2}{*}{ gI hm1amplification } \\
\hline & R:TTAATTAAGCGGTGGCGCGAGACGCCCGGCGCG & \\
\hline \multirow{2}{*}{ gE HR R arm } & F:TTAATTAAGTCCCGCCCCGCTTAAATACCGGGAG & \multirow{2}{*}{ gE hm1amplification } \\
\hline & R:AAGCTTACGTCCAGGGCGTCGGCGTCCGTCAGCCCG & \\
\hline \multirow{2}{*}{ GFP } & F:ATCGATATGGTGAGCAAGGGCGAGGAGCTG & \multirow{2}{*}{ GFP amplification } \\
\hline & R:AGATCTTCACTTGTACAGCTCGTCCATGCCG & \\
\hline \multirow{2}{*}{ mCherry } & F:ATCGATATGGTGAGCAAGGGCGAGGAGGATAAC & \multirow{2}{*}{ mCherry amplification } \\
\hline & R:AGATCTTCACTTGTACAGCTCGTCCATGCCG & \\
\hline \multirow{2}{*}{ sgRNA-TK } & F:CACCGCTGGCGCGCTTCATCGTCGGGG & \multirow{2}{*}{ TK sgRNA cloning } \\
\hline & R:AAACCCCCGACGATGAAGCGCGCCAGC & \\
\hline \multirow{2}{*}{ sgRNA-gE } & F:CACCGAACGCCACCGCGGACGAGTCGG & \multirow{2}{*}{ gE sgRNA cloning } \\
\hline & R:AAACCCGACTCGTCCGCGGTGGCGTTC & \\
\hline \multirow{2}{*}{ sgRNA-gI } & F:CACCGGCGTACTCGCGCGTGTAGCAGG & \multirow{2}{*}{ gI sgRNA cloning } \\
\hline & R:AAACCCTGCTACACGCGCGAGTACGCC & \\
\hline \multirow{2}{*}{$\mathrm{gI} / \mathrm{gE}$} & F:GCCGACGACCCCCGCGCCCCCCCGGGGGAC & \multirow{2}{*}{$\mathrm{gI} / \mathrm{gE}$ gene verification } \\
\hline & R:ACGTCCAGATCCCGGCCAGCACGGCGCCGTC & \\
\hline \multirow{2}{*}{ TK } & F:CCGGTATTTACGATGCGCAGACCCGGAAGC & \multirow{2}{*}{ TK gene verification } \\
\hline & R:CCTCCATGCCGCGCGCCTGCGCCGCCACGG & \\
\hline \multirow{2}{*}{$\mathrm{gD}$} & F:TGCCCGCGCCGACCTTCCCCCCGCCCGCGTAC & \multirow{2}{*}{ gD gene verification } \\
\hline & R:GCGTACGGCGTGGCGGCGGCGTAGGCCCGCGG & \\
\hline
\end{tabular}

\subsection{DNA Transfection and Purification of Recombinant Virus}

The PRV GX genome was extracted as previously described [29,30]. To generate the recombinant PRV (rGX $\Delta \mathrm{gE} / \mathrm{gI}$ or $\mathrm{rGX} \Delta \mathrm{TK} / \mathrm{gE} / \mathrm{gI})$, HEK293T cells were co-transfected with $1 \mu \mathrm{g}$ of the PRV genome, $500 \mathrm{ng}$ of cas9 plasmid sgRNA-gE and sgRNA-gI (or sgRNA-gE, sgRNA-gI, and sgRNA-TK), $200 \mathrm{ng}$ of fragment gIhm-loxN-CMV-mCherry-SV40polyA-loxN-gEhm (or TKhm1-loxP-CMV- GFP-SV40polyAloxP-TKhm2 and gIhm-loxN-CMV-mCherry-SV40polyA-loxN-gEhm) using Lipofectamine 2000 (Invitrogen, Carlsbad, CA, USA) for $48 \mathrm{~h}$. Then, the cells were collected and subjected to three freeze-thaw cycles. Recombinant PRV was purified from the cell lysates using plaque purification in PK-15 cells overlaid with 1\% low-melting-point agarose and 2\% FBS in PBS. After 10 rounds of purification, the plaques were measured via fluorescent microscopy.

\subsection{Cre-Mediated Recombination In Vitro}

Conditions for Cre-mediated recombination in vitro were described in a previous study [31]. Briefly, $2 \mu \mathrm{g}$ of rGX $\Delta \mathrm{gE} / \mathrm{gI}$ or $\mathrm{rGX} \Delta \mathrm{TK} / \mathrm{gE} / \mathrm{gI}$ genome, $50 \mathrm{mM}$ Tris-HCI, $\mathrm{pH}$ 7.5/33 mM NaCI/10 mM $\mathrm{MgCl} 2$ and 8 units of Cre recombinase (New England Biolabs, Beijing, China) were mixed and incubated at $37^{\circ} \mathrm{C}$ for $30 \mathrm{~min}$. The reactions were stopped by heating the samples at $70{ }^{\circ} \mathrm{C}$ for 10 min to inactivate Cre, and then HEK293T cells were transfected with DNA. Fluorescent gene excision was developed by three rounds of plaque purification, as previously described [24].

\subsection{In Vitro Growth Properties}

One-step growth kinetics and plaque sizes of all the viruses were detected in this study, as previously described [20]. 


\subsection{Animal Experiments}

The 6-week-old female Balb/c mice (20-25 g) were purchased from the Laboratory Animal Research Center of Huazhong Agricultural University (Wuhan, China). The 5-week-old crossbred weaning piglets were purchased from the experimental farm of Huazhong Agricultural University. All experimental protocols were conducted according to the Research Ethics Committee of College of Veterinary Medicine, Huazhong Agricultural University, Hubei, China (No. 42000600035617, 17 September 2019).

Experiment 1: The BALB/c mice were randomly divided into 9 groups ( $n=5 /$ group). The mice in Groups A, B, C, or D were intraperitoneally inoculated with $100 \mu \mathrm{L}$ of different doses $\left(10^{2}, 10^{3}, 10^{4}\right.$, or $10^{5} \mathrm{TCID} 50$ ) of rGX $\Delta \mathrm{gE} / \mathrm{gI}$. The mice in Groups E, F, G, or H were intraperitoneally inoculated with $100 \mu \mathrm{L}$ of different doses $\left(10^{2}, 10^{3}, 10^{4}\right.$, or $\left.10^{5} \mathrm{TCID} 50\right)$ of $\mathrm{rGX} \Delta \mathrm{TK} / \mathrm{gE} / \mathrm{gI}$. Mice in Group I were injected with PBS serving as control. Then, clinical signs were monitored daily. At 14 days post-inoculation, all surviving mice were euthanatized, and the brain and lung tissues were collected.

Experiment 2: Pigs were randomly divided into three groups ( $n=4 /$ group). The piglets were seronegative for PRV, which were identified using a commercially available PRV-gB antibody detection kit (Combined Biotech Co., Ltd., Shenzhen, China). The pigs in Group A or B were intramuscularly immunized with $10^{6}$ TCID50 rGX $\Delta \mathrm{gE} / \mathrm{gI}$ or $\mathrm{rGX} \Delta \mathrm{TK} / \mathrm{gE} / \mathrm{gI}$. Pigs in Group C were treated with $1 \mathrm{~mL}$ of PBS serving as control. The pigs were boosted with the same dose at 21 days post-immunization (dpi) and intranasally challenged with $10^{7}$ TCID50 virulent PRV GX strain at three weeks after the booster vaccination. Clinical signs were recorded daily for up to 16 days.

\subsection{Flow Cytometry}

The frequencies of IFN- $\gamma$-producing $\mathrm{CD}^{+}{ }^{+} \mathrm{CD} 4^{+}$and $\mathrm{CD}^{+}{ }^{+} \mathrm{CD} 8^{+}$T-cells from the $\mathrm{CD}^{+}$lymphocytes in the blood were analyzed using flow cytometry. Samples were collected at 14 days after the booster immunization. Then, sample processing and flow cytometry analysis were carried out as described in a previous report [32]. Mononuclear cells from the blood were isolated based on the previous description [33]. The mononuclear cells were stimulated in vitro with inactivated PRV $(\mathrm{MOI}=1)$ for $17 \mathrm{~h}$ before intracellular staining, as previously described [32].

\subsection{PRV-gD Specific Antibodies Measurement}

The levels of PRV-gD specific antibodies in the serum were measured using an indirect enzyme-linked immunosorbent assay (ELISA). Briefly, the 96-well flat-bottomed microtiter plates were incubated with $0.5 \mu \mathrm{g}$ per well of purified gD protein in coating buffer $(\mathrm{pH} 9.5)$ at $4{ }^{\circ} \mathrm{C}$ overnight, and blocked with $1 \%$ bovine serum albumin at $37^{\circ} \mathrm{C}$ for $1 \mathrm{~h}$. Then, the serially diluted serum samples were added into the plate and incubated for $1 \mathrm{~h}$ at $37^{\circ} \mathrm{C}$. Horseradish peroxidase (HRP)-conjugated goat anti-swine IgG (1:5000) (AntGene Bio Co., Ltd.,Wuhan, China) was used to cover the plate for $1 \mathrm{~h}$ at $37^{\circ} \mathrm{C}$. The serum PRV-gD specific antibody titers were measured at wavelength $450 \mathrm{~nm}$. The antibody endpoint titer was calculated based on the highest dilution, which gave an OD450 twice that of the naïve group without dilution.

\subsection{Serum Neutralisation Test}

Serum neutralizing antibody titer was detected as previously described [34,35]. Briefly, the serum samples were diluted using PBS. The 96-well flat-bottomed tissue culture plates (Thermofisher, Waltham, MA, USA) were covered with the diluted serum samples and supplemented with a viral suspension with a titer of 200 TCID50 PRV GX strain in $50 \mu \mathrm{L}$. After incubation for $1 \mathrm{~h}$ at $37^{\circ} \mathrm{C}$, the plates were incubated with $50 \mu \mathrm{L}$ of the PK-15 cell suspension for 3 days. Finally, the PRV-specific neutralizing antibody titer was analyzed and expressed as the reciprocal of the highest dilution while PK-15 cell infection was inhibited. 


\subsection{Virus Isolation}

Rectal and nasal swabs were collected everyday post-immunization or post-challenge, and then the virus was isolated according to the previous description [18].

\subsection{Hematoxylin and Eosin (HE) Staining}

Brain and lung tissues were fixed in $10 \%$ neutral-buffered formalin, subjected to paraffin embedding, and then cut into $4-\mu \mathrm{m}$ thick slices. The slices were deparaffinized, rehydrated and stained with hematoxylin and eosin. The photograph was taken under a light microscope.

\subsection{Statistical Analysis}

All data were presented as the mean \pm standard deviation (SD) and analyzed using Graphpad Prism 6.0 software. Comparisons were conducted via one-way ANOVA, followed by Tukey's test. A $p$ value less than 0.05 was considered as statistically significant.

\section{Results}

\subsection{Generation and Identification of $g E / g I$ (or TK/gE/gI)-Deleted Recombinant PRVs via a CRISPR/Cas9- and} Cre-lox-Based System

In order to obtain gE/gI (or TK/gE/gI)-deleted recombinant PRV (rGX $\Delta \mathrm{gE} / \mathrm{gI}$ or $\mathrm{rGX} \Delta \mathrm{TK} / \mathrm{gE} / \mathrm{gI}$ ), CRISPR/Cas9 and Cre-lox-based systems were applied into producing new PRV virulent variants. The amino acid sequences of major antigens, gB and gD of PRV GX, are shown in Figure 1A,B, and they exhibited some variations and deletion compared with the Bartha strain and previous pandemic Ea strain by sequence alignment.

We then established an express vaccine development strategy using two highly efficient gene edit systems, the CRISPR/Cas9 and Cre/Lox systems. HEK293T cells were co-transfected with the PRV genome, cas9 plasmid sgRNA-gE and sgRNA-gI (or sgRNA-gE, sgRNA-gI and sgRNA-TK), fragment gIhm-loxN-CMV-mCherry-SV40polyA-loxN-gEhm (or TKhm1-loxP-CMV-GFP-SV40polyAloxP-TKhm2 and gIhm-loxN-CMV-mCherry-SV40polyA-loxN-gEhm). Then, the cells were collected and subjected to single-cell FACS technique to purify recombinant PRV. Further, the Cre/Lox system was used to facilitate fluorescent marker genes excision. GFP (or GFP and mCherry) genes were flanked with LoxP and Lox N pairs, respectively (Figure 1C, Figure 2A). Fluorescence detection revealed that the recombinant viruses ( $\mathrm{rGX} \Delta \mathrm{gE} / \mathrm{gI}$ or $\mathrm{rGX} \Delta \mathrm{TK} / \mathrm{gE} / \mathrm{gI}$ ) expressing red or/and green fluorescence were successfully visualized (Figure 1D, Figure 2B). Subsequently, the recombinant PRV (rGX $\Delta \mathrm{gE} / \mathrm{gI}$ or $\mathrm{rGX} \Delta \mathrm{TK} / \mathrm{gE} / \mathrm{gI}$ ) were collected and infected HEK293T cells. HEK293T cells with fluorescence were analyzed using the single-cell FACS technique and plated one cell per well to a 96-well plate pre-cultured with HEK293T cells. Fluorescence detection was conducted (Figure 1E, Figure 2C). Then, one round of plaque purification was performed to obtain the pure recombinant viruses when the wells displayed maximum fluorescence overlapping signals (Figure 1F, Figure 2D). In addition, PCR amplification confirmed the purity of the recombinant virus. The results demonstrated that recombinant PRV (rGX $\triangle \mathrm{gE} / \mathrm{gI}$ ) showed TK amplification, whereas $\mathrm{gE} / \mathrm{gI}$ amplification was negative (Figure $1 \mathrm{H}$ ). Similarily, TK and gE/gI gene amplification exhibited negative in recombinant PRV (rGX $\Delta \mathrm{TK} / \mathrm{gE} / \mathrm{gI}$; Figure 2F). Finally, the fluorescence markers were removed in vaccine candidates due to vaccine safety concerns and regulation. Cre-treated recombinant viruses were obtained and infected to HEK293T cells. The fluorescent gene was excised through four rounds of plaque purification (Figure 1G, Figure 2E). Further, one-step growth kinetics demonstrated that the rGX $\Delta \mathrm{gE} / \mathrm{gI}$ and $\mathrm{rGX} \Delta \mathrm{TK} / \mathrm{gE} / \mathrm{gI}$ strains propagated slightly slower than the parental strain GX (Figure 2G). These results indicated that the $\mathrm{gE} / \mathrm{gI}$ (or TK/gE/gI)-deleted recombinant virus was successfully generated using the CRISPR/Cas9- and Cre-lox-based systems. 
A

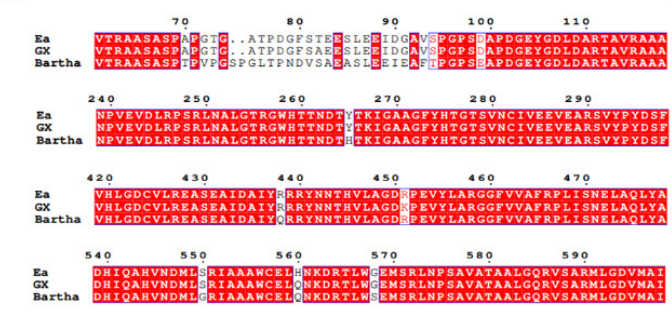

B

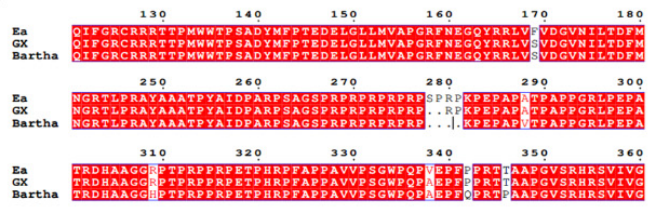

D

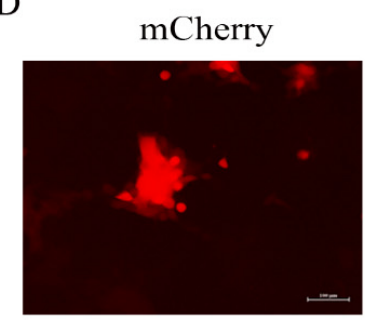

F

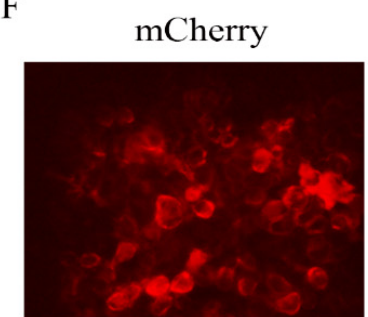

$\mathrm{H}$

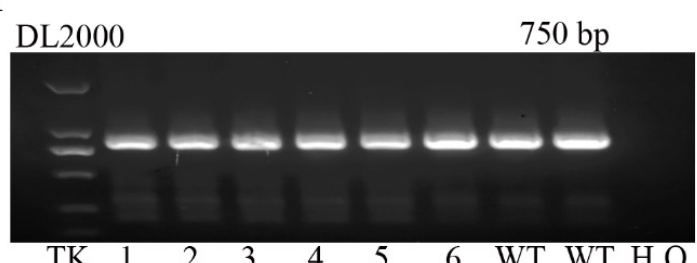

$\mathrm{C}_{(1) \mathrm{CRISPR} / \mathrm{dCas} 9 \text { based gene recombination }}$

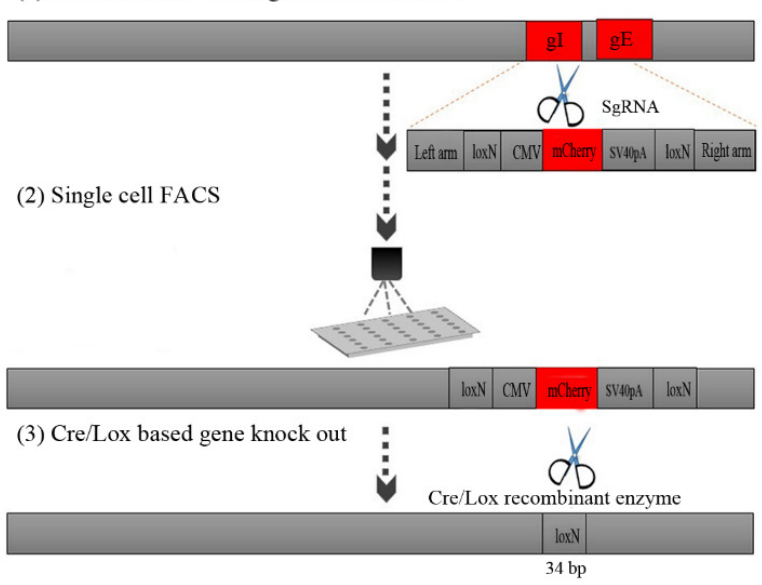

E

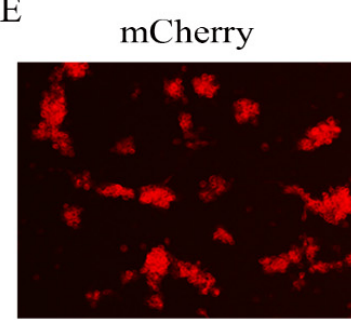

G

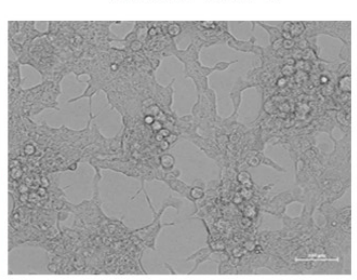

PK-15

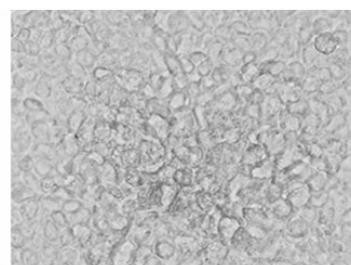

750 bp

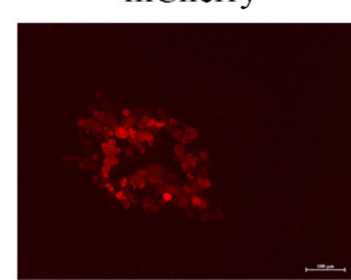

DL2000
HEK-293T

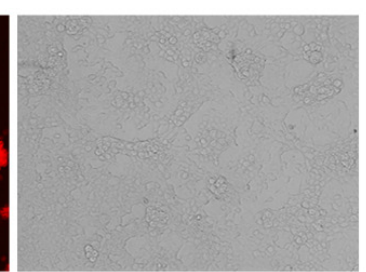

HEK-293T

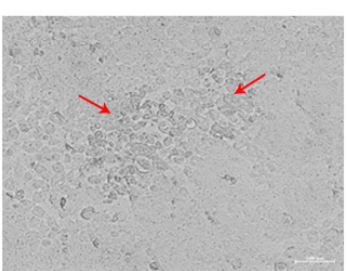

900 bp

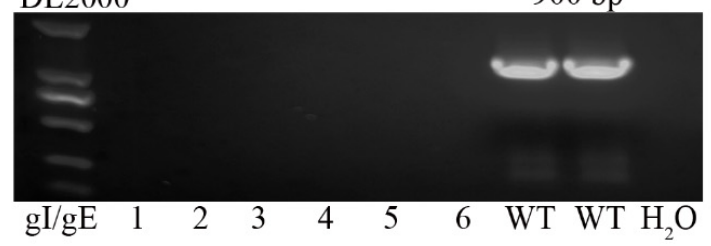

Figure 1. The gE/gI-gene-deleted recombinant PRV (rGX $\triangle \mathrm{gE} / \mathrm{gI})$ was developed using CRISPR/Cas9 and Cre/Lox systems. (A,B) Amino acid sequence alignments of PRV gB and gD (PRV GX strain, PRV Bartha strain, and the previous pandemic strain PRV Ea). (C) The vaccine development strategy was performed. PRV virulent gene $\mathrm{gE}$ and $\mathrm{gI}$ were replaced with mCherry via CRISPR/Cas9 system-assisted homologous recombination. Recombinant virus purification was accelerated using single-cell FACS. The mCherry gene was deleted through the Cre/Lox system. (D) Fluorescence detection was performed when HEK293T cells were co-transfected with pX335-Cas9-sgRNA-gE, pX335-Cas9-sgRNA-gI, gIhm-loxN-CMV-mCherry-SV40polyA-loxN-gEhm donor template and PRV genome. (E) Single cells with fluorescent gene recombinant PRV were selected using FACS. (F) Plaque purification of gE/gI-gene-deleted recombinant PRV in agarose-DMEM plates. (G) Plaque purification for fluorescent gene excision PRV following Cre- recombinase treatment. Arrow indicated cell plaques. (H) PCR verification of $\mathrm{gE} / \mathrm{gI}$ gene deletion. 


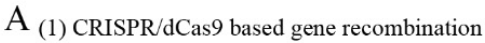

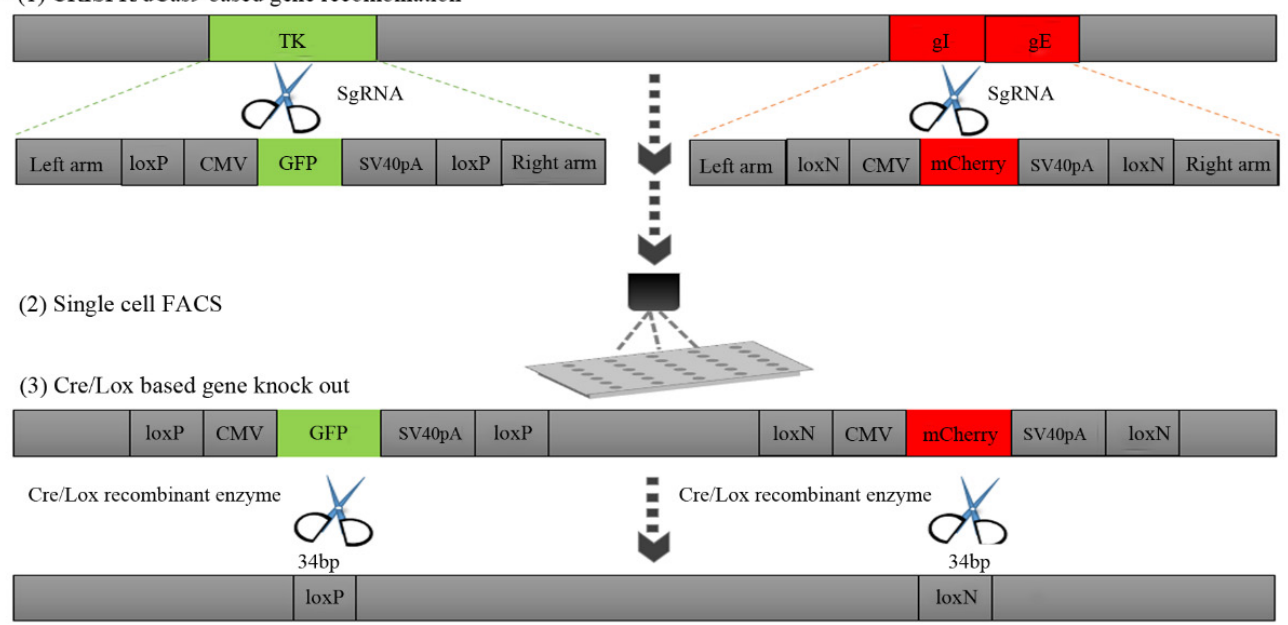

B
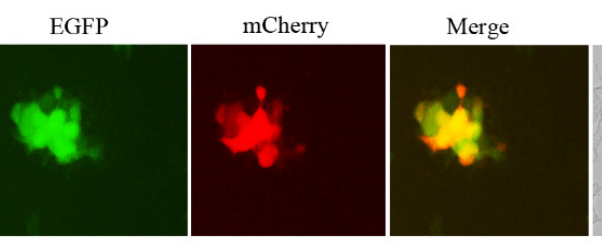

HEK-293T

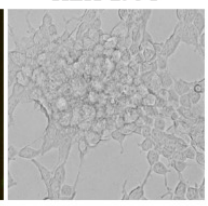

F $\quad$ DL5000

C

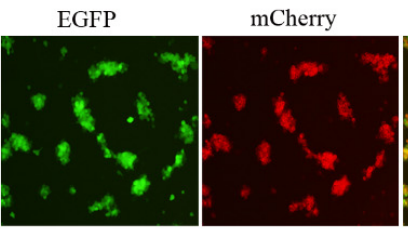

Merge

HEK-293T

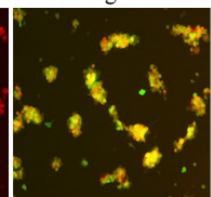

D EGFP

mCherry

Merge
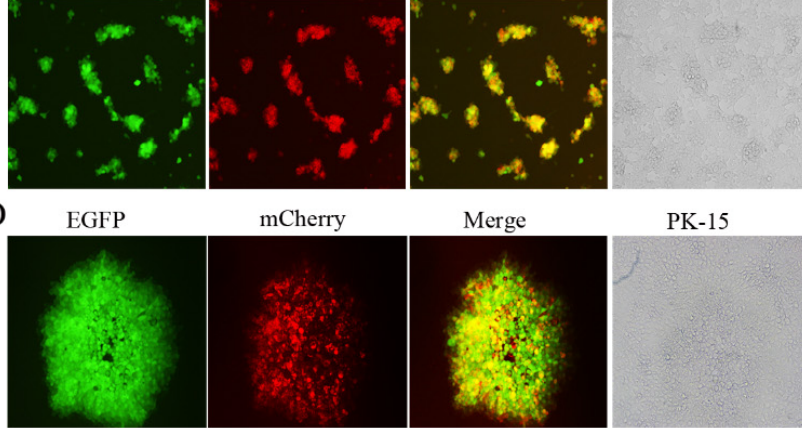

PK-15

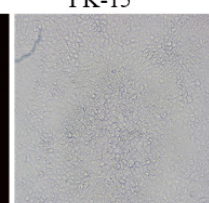

E mCherry

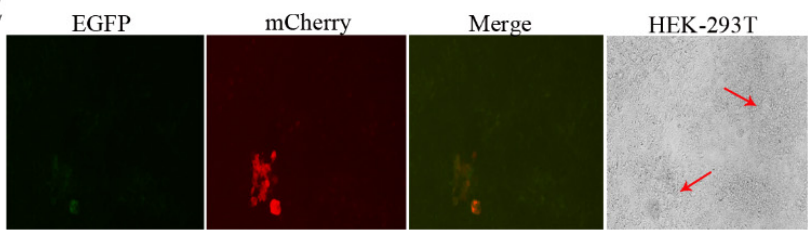

HEK-293T

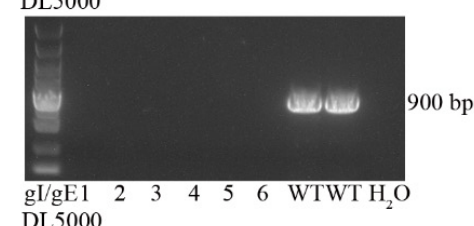

DL5000

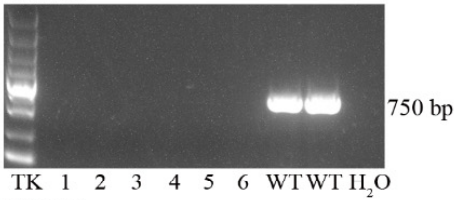

DL5000

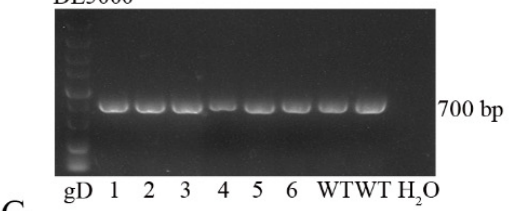

$\mathrm{G}$

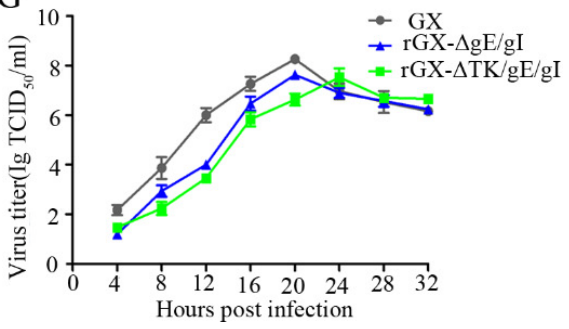

Figure 2. The gE/gI/TK-gene-deleted recombinant PRV (rGX $\Delta \mathrm{TK} / \mathrm{gE} / \mathrm{gI}$ ) was developed using CRISPR/Cas9 and Cre/Lox systems. (A) Overview of the strategy for vaccine development. PRV virulent gene TK and $\mathrm{gE} / \mathrm{gI}$ were replaced with GFP and mCherry respectively via CRISPR/Cas9 system-assisted homologous recombination. Recombinant virus purification was accelerated using single-cell FACS. The GFP and mCherry gene were deleted through the Cre/Lox system. (B) Fluorescence detection was conducted while HEK293T cells were co-transfected with pX335-Cas9-sgRNA-TK, pX335-Cas9-sgRNA-gE, pX335-Cas9-sgRNA-gI, TKhm1-loxP-CMV-GFP-SV40polyA-loxP-TKhm2, and gIhm-loxN-CMV-mCherry-SV40polyA-loxN-gEhm donor templates, PRV genome. Scale bar, $100 \mu \mathrm{m}$. (C) Single cells with fluorescent gene recombinant PRV were sorted through FACS. Scale bar, $100 \mu \mathrm{m}$. (D) Plaque purification of gE/gI/TK-gene-deleted recombinant PRV in agarose-DMEM plates. Scale bar, $100 \mu \mathrm{m}$. (E) Plaque purification for fluorescent genes excision PRV following Cre-recombinase treatment. Arrows indicate cell plaques. Scale bar, $100 \mu \mathrm{m}$. (F) PCR verification of TK and gE/gI gene deletion. (G) One-step growth curves of the recombinant viruses in BHK-21 cells. 


\subsection{Safety of $r G X \Delta g E / g I$ and $r G X \Delta T K / g E / g I$ in Mice}

We then evaluated the safety of $\mathrm{rGX} \Delta \mathrm{gE} / \mathrm{gI}$ and $\mathrm{rGX} \Delta \mathrm{TK} / \mathrm{gE} / \mathrm{gI}$ in mice. Results revealed that morbidity and mortality of mice immunized with $\mathrm{rGX} \Delta \mathrm{TK} / \mathrm{gE} / \mathrm{gI}$ or PBS were not affected. However, the $\mathrm{rGX} \Delta \mathrm{gE} / \mathrm{gI}$-inoculated mice displayed high morbidity and mortality (Table 2). Additionally, HE staining demonstrated that no histopathological lesions were observed in mice immunized with $\mathrm{rGX} \triangle \mathrm{TK} / \mathrm{gE} / \mathrm{gI}$ or PBS. In contrast, purkinje neuron injury in the brains, and slight hemorrhages and congestion in the lungs were observed and obvious in mice immunized with the rGX $\triangle \mathrm{gE} / \mathrm{gI}$ group (Figure $3 \mathrm{~A}, \mathrm{~B}$ ). These findings suggest that $\mathrm{rGX} \Delta \mathrm{TK} / \mathrm{gE} / \mathrm{gI}$ is safer than $\mathrm{rGX} \Delta \mathrm{gE} / \mathrm{gI}$ in mice.

Table 2. Outcome of infection with $\mathrm{rGX} \triangle \mathrm{TK} / \mathrm{gE} / \mathrm{gI}$ and $\mathrm{rGX} \triangle \mathrm{gE} / \mathrm{gI}$ in mice.

\begin{tabular}{cccccc}
\hline Groups & Doses (TCID50) & Amounts & Morbidity & Mortality & LD50 (TCID50) \\
\hline \multirow{2}{*}{ rGX- $\triangle \mathrm{TK} / \mathrm{gE} / \mathrm{gI}$} & $10^{5}$ & 5 & $0 / 5$ & $0 / 5$ & \\
& $10^{4}$ & 5 & $0 / 5$ & $0 / 5$ & \\
& $10^{3}$ & 5 & $0 / 5$ & $0 / 5$ & \\
$\mathrm{rGX}-\triangle \mathrm{gE} / \mathrm{gI}$ & $10^{2}$ & 5 & $0 / 5$ & $0 / 5$ & \\
& $10^{5}$ & 5 & $5 / 5$ & $5 / 5$ & \\
$\mathrm{PBS}$ & $10^{4}$ & 5 & $4 / 5$ & $3 / 5$ & $10^{3.68}$ \\
& $10^{3}$ & 5 & $2 / 5$ & $1 / 5$ & \\
\hline
\end{tabular}

A
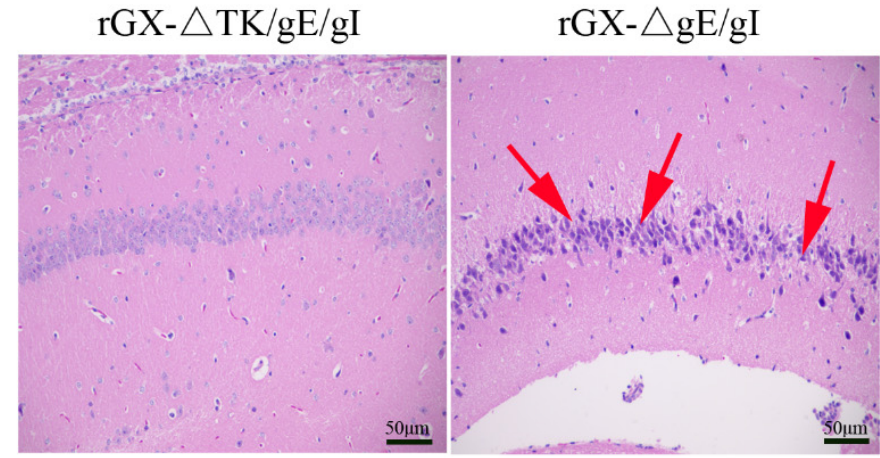

B
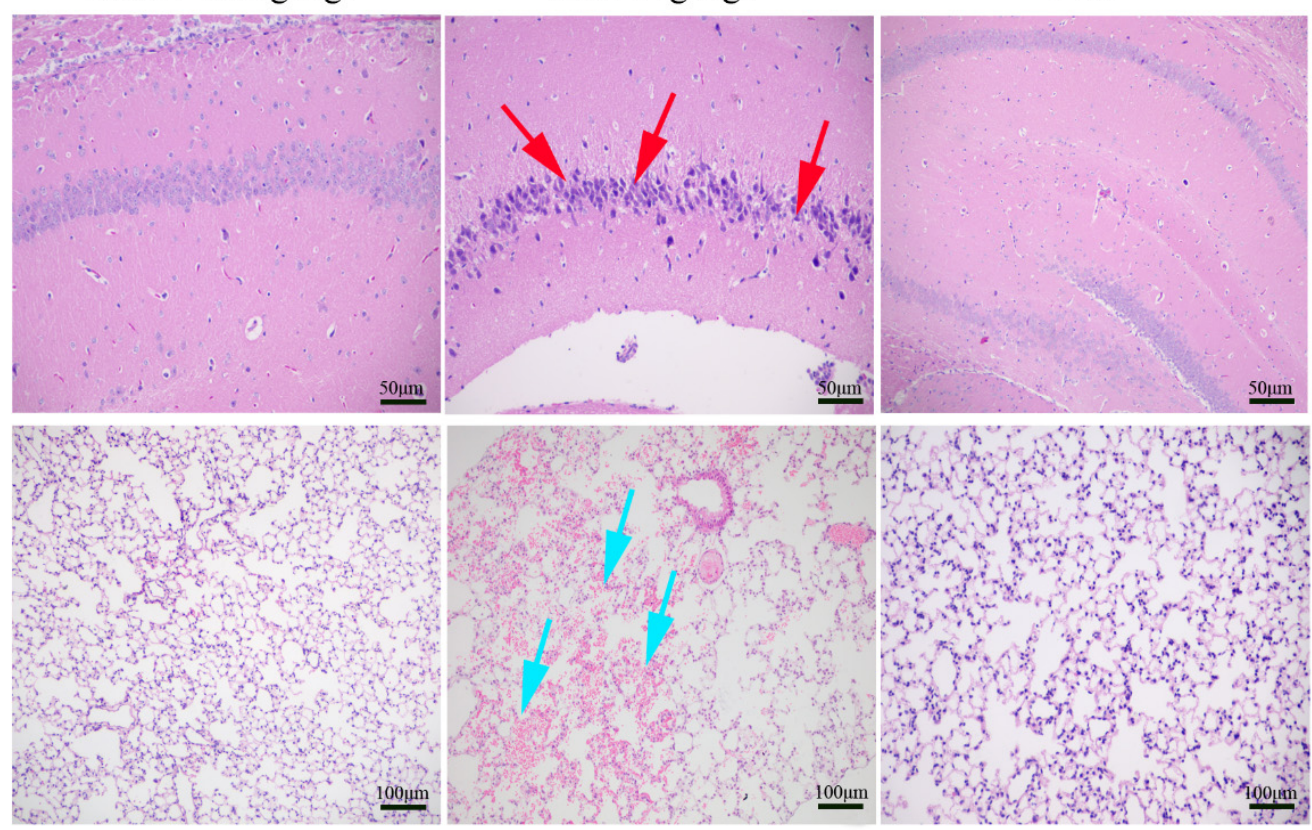

Figure 3. The effect of the gE/gI- and gE/gI/TK-gene-deleted PRVs on histopathological lesions in mice. $(\mathbf{A}, \mathbf{B})$ Pathological lesions of brain and lung tissues were detected using HE staining. Scale bar, 50 or $100 \mu \mathrm{m}$. Arrows indicate the cell infiltrates. HE, hematoxylin and eosin staining.

\subsection{The Production of IFN- $\gamma$-Producing $C D 4^{+}$and $C D 8^{+}$T-Cells}

To examine the amount of IFN- $\gamma$-producing $\mathrm{CD}^{+}$and $\mathrm{CD} 8^{+}$T-cells, which are critical for virus elimination, flow cytometry analysis was performed. We found that $\mathrm{rGX} \Delta \mathrm{TK} / \mathrm{gE} / \mathrm{gI}$ and $\mathrm{rGX} \Delta \mathrm{gE} / \mathrm{gI}$ significantly elevated the IFN- $\gamma$-producing $\mathrm{CD}^{+}$and $\mathrm{CD}^{+}$T-cells in pigs. However, the numbers of IFN- $\gamma$-producing $\mathrm{CD} 4^{+}$and $\mathrm{CD} 8^{+}$T-cells were not affected between the $\mathrm{rGX} \Delta \mathrm{TK} / \mathrm{gE} / \mathrm{gI}$ group and the $\mathrm{rGX} \Delta \mathrm{gE} / \mathrm{gI}$ group. (Figure $4 \mathrm{~A}, \mathrm{~B}$ ). The data imply that $\mathrm{rGX} \Delta \mathrm{TK} / \mathrm{gE} / \mathrm{gI}$ and $\mathrm{rGX} \Delta \mathrm{gE} / \mathrm{gI}$ immunizations induce equivalent PRV-specific T-cell immune responses. 

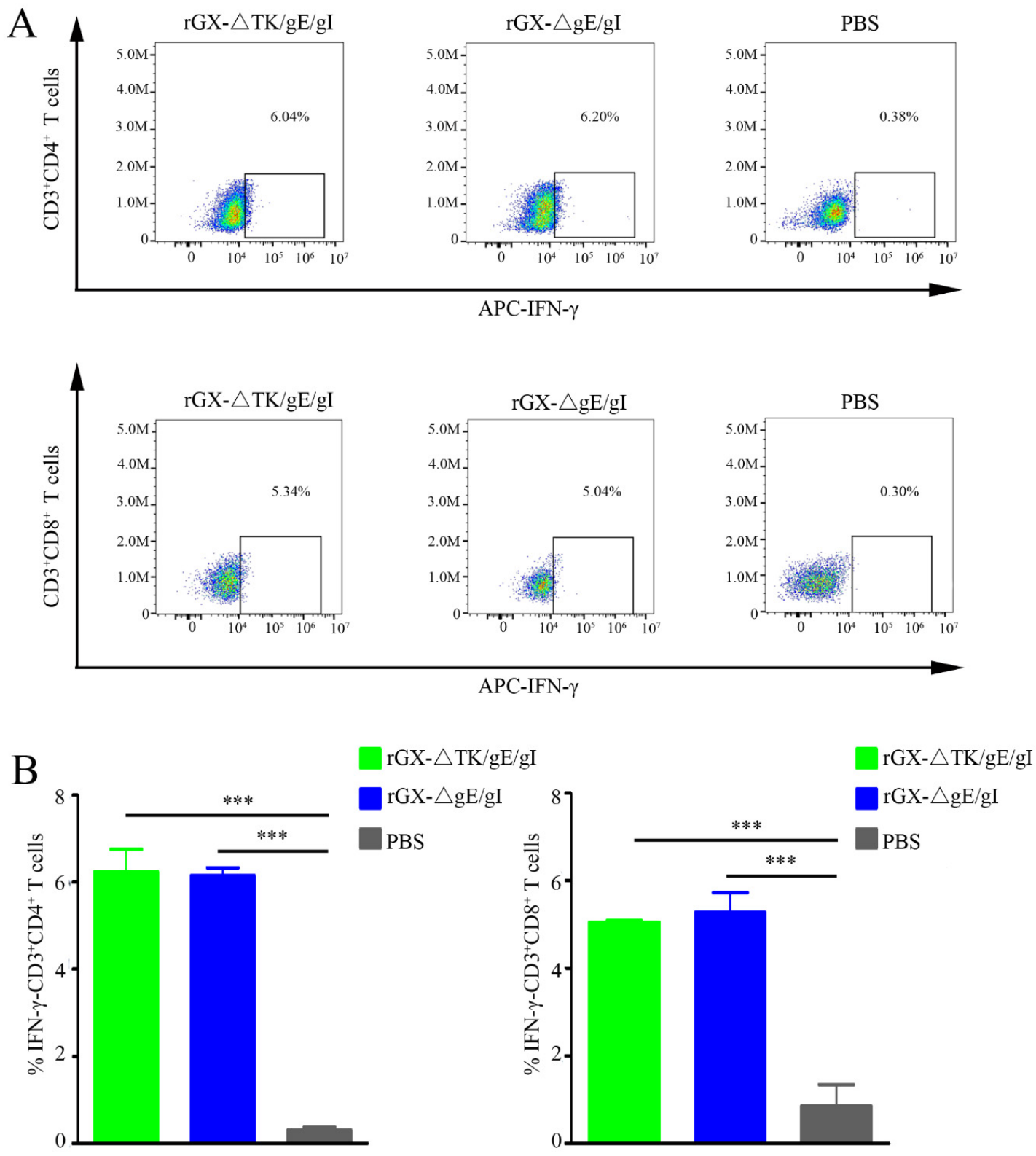

Figure 4. The $\mathrm{rGX} \Delta \mathrm{gE} / \mathrm{gI}$ or $\mathrm{rGX} \Delta \mathrm{TK} / \mathrm{gE} / \mathrm{gI}$ facilitated production of IFN- $\gamma$-producing $\mathrm{CD} 4^{+}$and $\mathrm{CD} 8^{+}$ T-cells in the blood. (A) Flow cytometry analysis was used to measure the IFN- $\gamma$-producing $\mathrm{CD}^{+}$and CD8 ${ }^{+}$T-cells. (B) The calculation of IFN- $\gamma$-producing CD4 ${ }^{+}$and CD8 ${ }^{+}$T-cells. $n=4 .{ }^{* * *} p<0.001$.

\subsection{Immunogenicity of $r G X \Delta g E / g I$ and $r G X \Delta T K / g E / g I$ in Pigs}

In order to monitor PRV gD-specific antibody responses and NAbs against the PRV GX strains, the serum samples were collected at $0,14,28,42,56$, and 63 after vaccination. ELISA analysis demonstrated that there was no difference shown in PRV gD-specific antibody from rGX $\Delta \mathrm{TK} / \mathrm{gE} / \mathrm{gI}$ and $\mathrm{rGX} \Delta \mathrm{gE} / \mathrm{gI}$ groups at $0,14,28,42,56$, and 63 days post-immunization (Figure 5A). Moreover, neutralizing antibody assay revealed that the levels of NAbs against the GX strain were similar in the two vaccinated groups (Figure 5B). These results indicate that $\mathrm{rGX} \Delta \mathrm{TK} / \mathrm{gE} / \mathrm{gI}$ and $\mathrm{rGX} \Delta \mathrm{gE} / \mathrm{gI}$ immunizations induce equivalent PRV-specific humoral immune responses. 
A

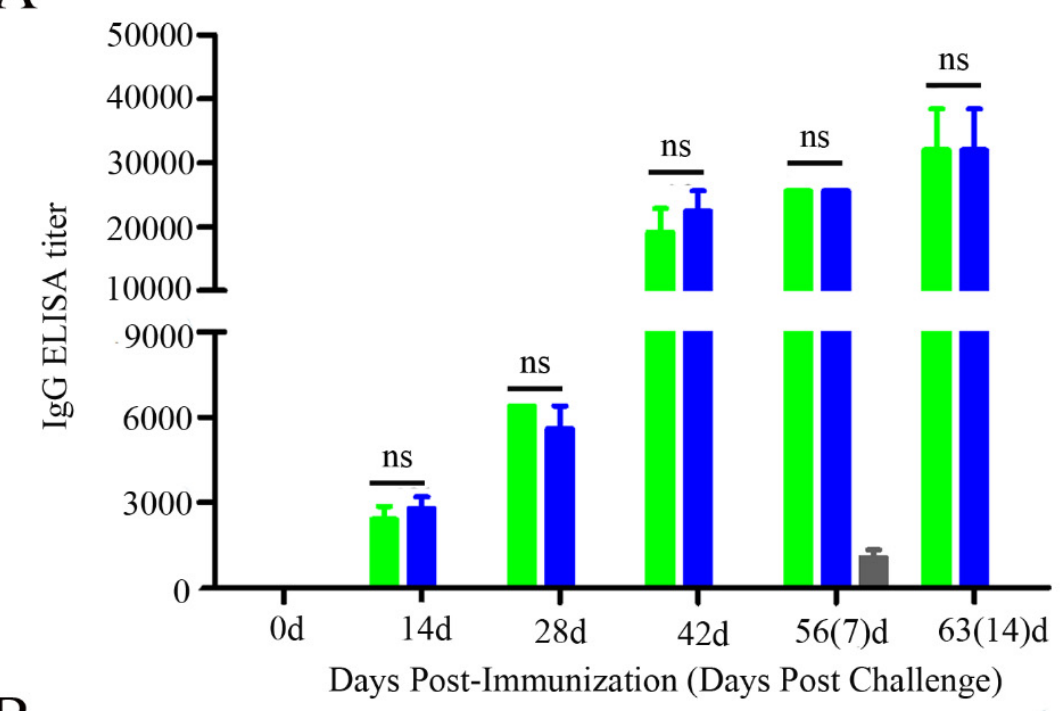

B

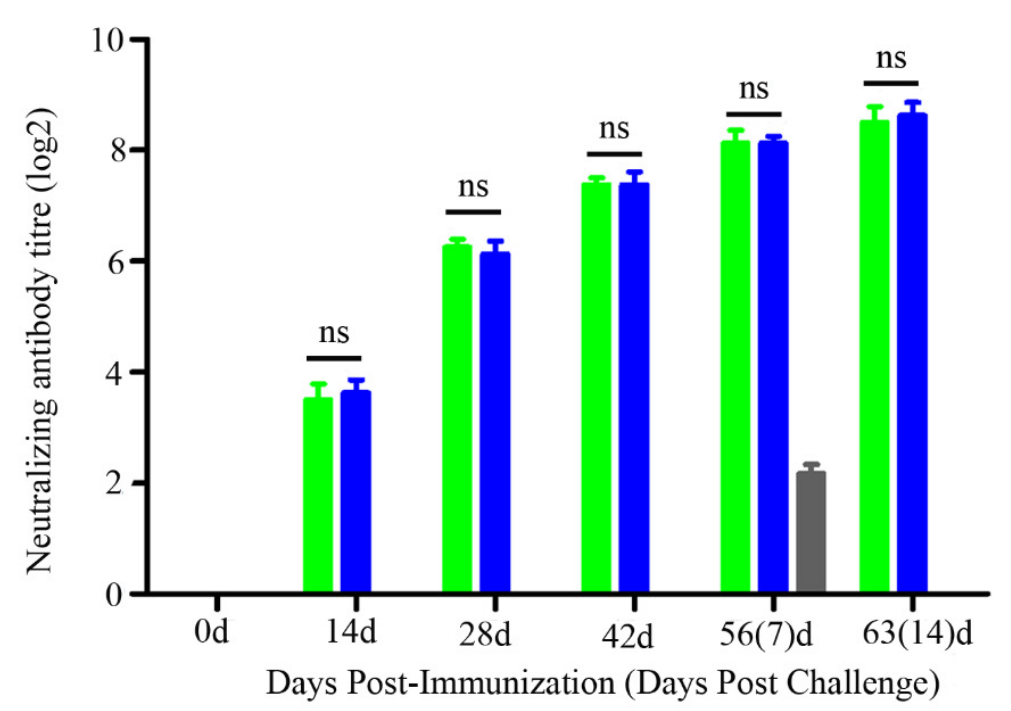

$\mathrm{rGX}-\triangle \mathrm{TK} / \mathrm{gE} / \mathrm{gI}$

$\mathrm{rGX}-\triangle \mathrm{gE} / \mathrm{gI}$

PBS
$\mathrm{rGX}-\triangle \mathrm{TK} / \mathrm{gE} / \mathrm{gI}$

$\mathrm{rGX}-\triangle \mathrm{gE} / \mathrm{gI}$

PBS

Figure 5. PRV-gD-specific IgG titre and neutralizing antibody titre were evaluated. (A) The indirect ELISA was used to detect gD-specific IgG titer from serum samples at 0,14, 28, 42, 56, and 63 dpi. (B) Neutralizing antibody titer was examined in the serum of the immunized pigs. The neutralizing ability of antisera generated against PRV-GX strain was calculated and presented as the log2 of the reciprocal of the highest serum dilution when PK-15 cell infection was inhibited. $n=4$. ns represents not significant.

\subsection{Protection of Pigs Immunized with $r G X \Delta g E / g I$ and $r G X \Delta T K / g E / g I$ from Virulent Challenge}

In order to evaluate the protection efficacy of the two genetically deleted PRV strains against lethal GX challenge, pigs were challenged intranasally with a highly virulent PRV GX strain. No clinical signs were observed in pigs immunized with $\mathrm{rGX} \Delta \mathrm{gE} / \mathrm{gI}$ and $\mathrm{rGX} \Delta \mathrm{TK} / \mathrm{gE} / \mathrm{gI}$ after virulent challenge. However, pigs in the PBS group displayed typical PR signs (depression, anorexia, cough, diarrhea, and systemic neurological signs) with high fever $\left(40.5-42{ }^{\circ} \mathrm{C}\right)$ from $2 \mathrm{dpc}$ till death (Figure $\left.6 \mathrm{~A}\right)$. Meanwhile, the fever frequencies were the highest in the PBS group (21/25; Table 3). In addition, all pigs died within $10 \mathrm{dpc}$ in the PBS group, while pigs were survived in other groups (Figure 6B). The challenge virus was isolated from the nasal and rectal swabs of unvaccinated pigs at 1-16 dpc. In contrast, no viral shedding was detected in pigs vaccinated with $\mathrm{rGX} \Delta \mathrm{TK} / \mathrm{gE} / \mathrm{gI}$ and $\mathrm{rGX} \Delta \mathrm{gE} / \mathrm{gI}$ (Table 3). 


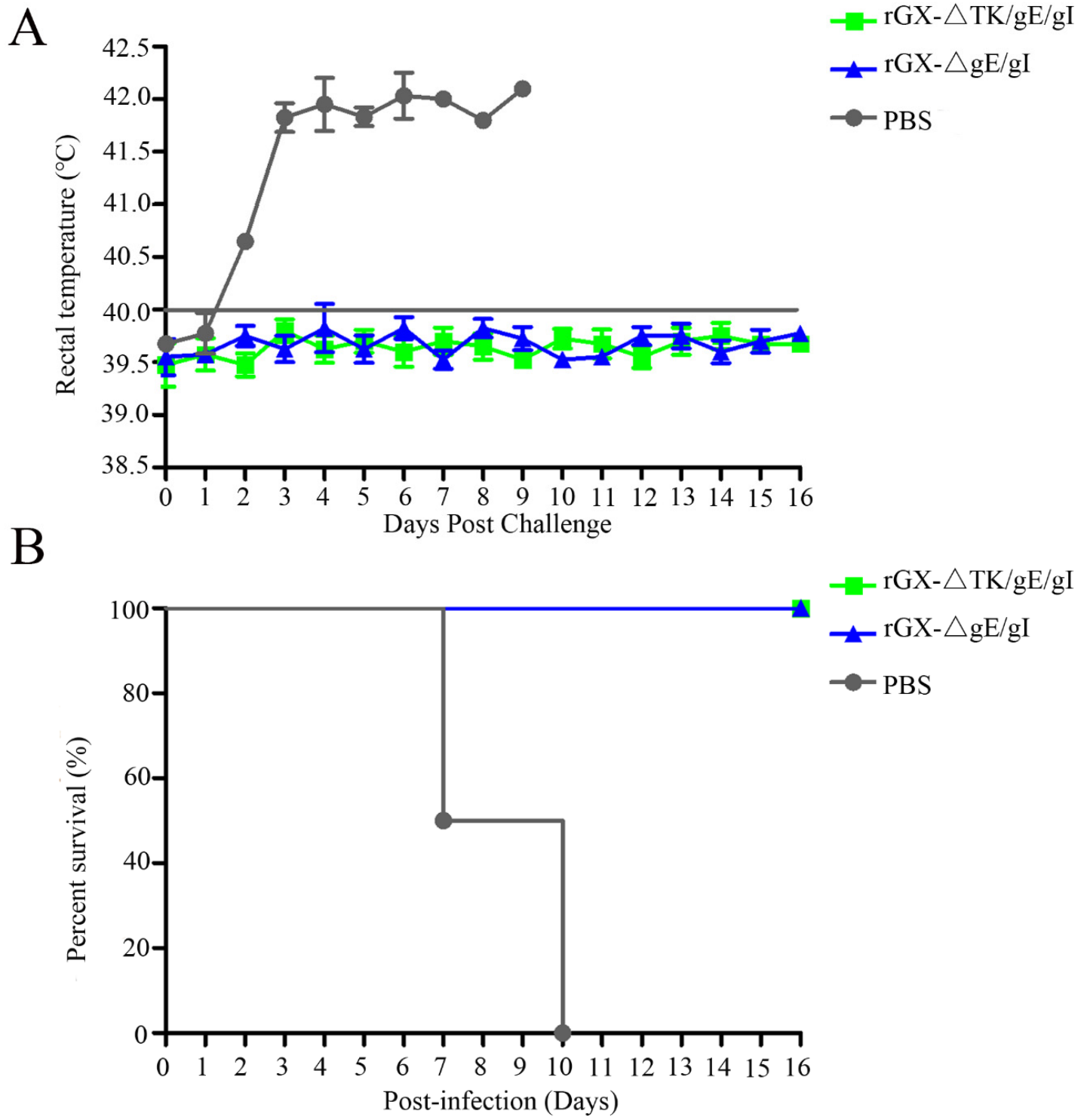

Figure 6. The effect of $\mathrm{rGX} \Delta \mathrm{gE} / \mathrm{gI}$ and $\mathrm{rGX} \Delta \mathrm{TK} / \mathrm{gE} / \mathrm{gI}$ on rectal temperature and survival rates in pigs after challenge. Pigs were challenged with virulent PRV GX strain (10 ${ }^{7}$ TCID50) at 49 dpi, then (A) rectal temperature was recorded and (B) survival rates were calculated. Rectal temperature $\geq 40.0^{\circ} \mathrm{C}$ was fever. $n=4$.

Table 3. Disease outcome in pigs inoculated following challenge with the highly virulent strain PRV-GX.

\begin{tabular}{cccccc}
\hline Group & $\begin{array}{c}\text { Fever } \\
\left(\geq \mathbf{4 0 . 5}{ }^{\circ} \mathbf{C}\right)\end{array}$ & $\begin{array}{c}\text { Days to Fever } \\
\text { Onset }\end{array}$ & $\begin{array}{c}\text { Fever } \\
\text { Frequency }\end{array}$ & $\begin{array}{c}\text { Survival } \\
\text { Rate }\end{array}$ & $\begin{array}{c}\text { Viral } \\
\text { Shedding }\end{array}$ \\
\hline $\mathrm{PBS}$ & $4 / 4$ & 2 & $21 / 25^{\mathrm{a}}$ & $0 / 4$ & $4 / 4$ \\
$\mathrm{rGX}-\triangle \mathrm{gE} / \mathrm{gI}$ & $0 / 4$ & - & $0 / 64$ & $4 / 4$ & $0 / 4$ \\
$\mathrm{rGX}-\triangle \mathrm{TK} / \mathrm{gE} / \mathrm{gI}$ & $0 / 4$ & - & $0 / 64$ & $4 / 4$ & $0 / 4$ \\
\hline
\end{tabular}

Groups of pigs $(n=4)$ were inoculated with $10^{6} \mathrm{TCID} 50$ of $\mathrm{rGX}-\triangle \mathrm{TK} / \mathrm{gE} / \mathrm{gI}$ or rGX- $\triangle \mathrm{gE} / \mathrm{gI}$ or PBS and then challenged with $1 \mathrm{~mL} 10^{7} \mathrm{TCID} 50 / 100 \mu \mathrm{L}$ of the PRV-GX strain at 49 days post-inoculation (dpi). Following challenge, fever, days to fever onset, fever frequency, and survival were recorded. Fever is defined as rectal temperature $\geq 40.5^{\circ} \mathrm{C}$. ${ }^{\text {a }}$, Days with fever/total days observed.

Further, after challenge, the HE staining revealed that the pigs in the PBS group suffered severe microscopic pathological lesions in multiple organs, such as obvious non-suppurative meningoencephalitis and hemorrhages in the brains, and congestion in the lungs. Moreover, 
the pigs in the rGX $\Delta \mathrm{gE} / \mathrm{gI}$-vaccinated group still had slight histopathological lesions, including meningoencephalitis, hemorrhages, and congestion in the lungs. In contrast, the pigs immunized with rGX $\Delta \mathrm{TK} / \mathrm{gE} / \mathrm{gI}$ did not show pathological lesions (Figure 7A,B).

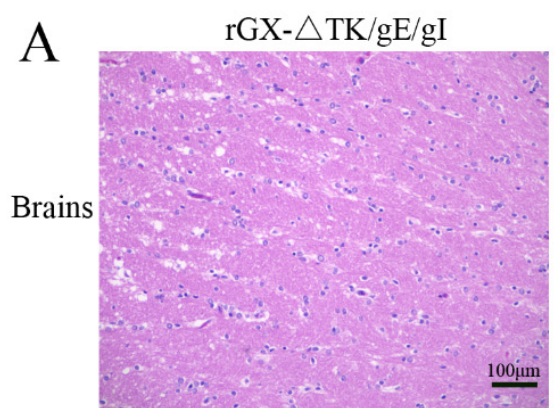

B

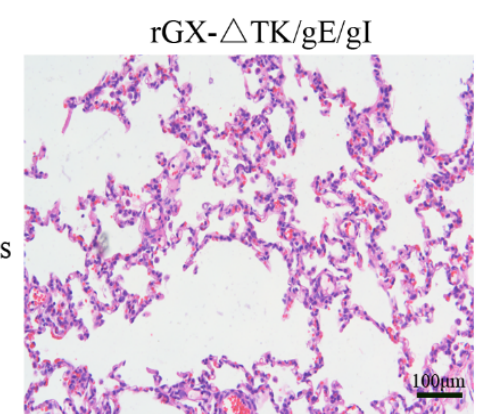

$\mathrm{rGX}-\triangle \mathrm{gE} / \mathrm{gI}$

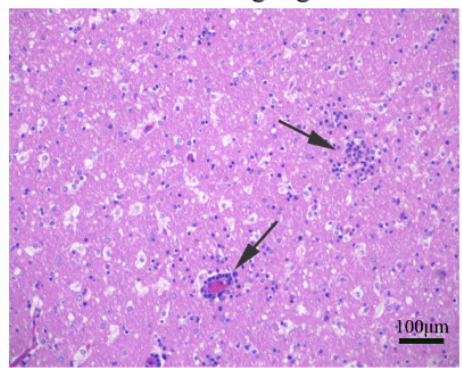

$\mathrm{rGX}-\triangle \mathrm{gE} / \mathrm{gI}$

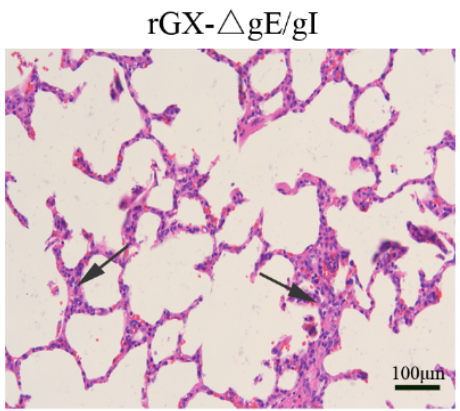

PBS

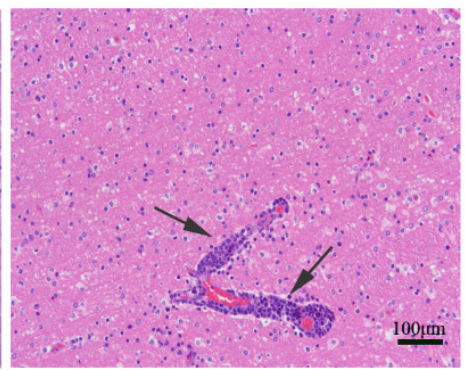

PBS

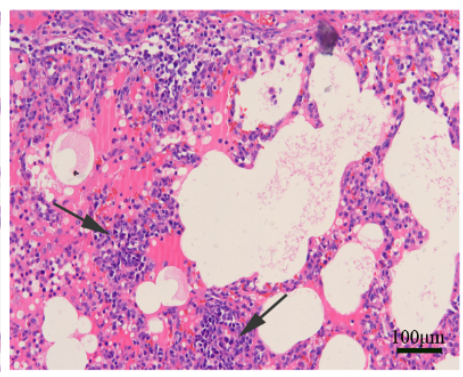

Figure 7. The effect of the gE/gI- and gE/gI/TK-gene-deleted PRV on histopathology in the brain and lung tissues of pigs. (A,B) HE staining was carried out to measure pathological lesions of brain and lung tissues in pigs. Scale bar, 50 or $100 \mu \mathrm{m}$. Arrows indicate the cell infiltrates. HE, hematoxylin and eosin staining.

\section{Discussion}

In the current study, we constructed the gE/gI- and TK/gE/gI-gene-deleted recombinant PRVs (rGX $\Delta \mathrm{gE} / \mathrm{gI}$ and $\mathrm{rGX} \Delta \mathrm{TK} / \mathrm{gE} / \mathrm{gI}$ ) using CRISPR/Cas9 and Cre/Lox systems. The comparison of $\mathrm{rGX} \Delta \mathrm{TK} / \mathrm{gE} / \mathrm{gI}$ and $\mathrm{rGX} \Delta \mathrm{gE} / \mathrm{gI}$ mediated by CRISPR/Cas9 and Cre/Lox systems was evaluated. $\mathrm{rGX} \Delta \mathrm{TK} / \mathrm{gE} / \mathrm{gI}$ was demonstrated to be safer than $\mathrm{rGX} \Delta \mathrm{gE} / \mathrm{gI}$ in mice. The $\mathrm{rGX} \Delta \mathrm{TK} / \mathrm{gE} / \mathrm{gI}$ and rGX $\Delta \mathrm{gE} / \mathrm{gI}$ significantly promoted PRV-specific T-cell immune response and humoral immune response in swine. Further analysis revealed that $\mathrm{rGX} \Delta \mathrm{TK} / \mathrm{gE} / \mathrm{gI}$ was safer compared with $\mathrm{rGX} \Delta \mathrm{gE} / \mathrm{gI}$ in swine.

Although there were significant efforts to control and eliminate PR, the disease has been endemic in swine in many places [36]. More effective PRV vaccines need to be explored to control the disease. Interestingly, it has been reported that piglets immunized with rPRVTJ-delgE were protected, whereas incomplete protection was provided by the Bartha-K61 vaccine [18], suggesting that rPRVTJ-delgE can update Bartha-K61 for the control of the currently epidemic PR. Notably, in our study, we isolated the PRV-GX strain and developed a gene-deleted vaccine for this variant. Several steps of single gene recombination and marker gene excision were performed to delete multiple genes to develop PRV vaccines. A PRV double gene deletion vaccine candidate was obtained, which involved approximately twenty rounds of time-consuming plaque purification [37]. In this study, to promote the multi-gene editing efficiency in viral genomes, two highly efficient gene edit systems, the CRISPR/Cas9 system and the Cre/Lox system, were combined. Further single-cell FACS technology was used to elevate virus purification efficiency. The $\mathrm{gE} / \mathrm{gI} / \mathrm{TK}$ and $\mathrm{gE} / \mathrm{gI}$ genes were deleted, and marker genes from recombinant viruses $\mathrm{rGX} \Delta \mathrm{TK} / \mathrm{gE} / \mathrm{gI}$ (GFP and mCherry) and $\mathrm{rGX} \Delta \mathrm{gE} / \mathrm{gI}$ (mCherry) were also excised using the $\mathrm{Cre} / \mathrm{lox}$ site-specific recombination system. The procedure was simple and easy to carry out, requiring only the readily harvested Cre protein [38]. Subsequently, the gE/gI- and gE/gI/TK-gene-deleted PRVs (rGX $\Delta \mathrm{gE} / \mathrm{gI}$ or $\mathrm{rGX} \Delta \mathrm{TK} / \mathrm{gE} / \mathrm{gI}$ ) were developed via the CRISPR/Cas9 and Cre/Lox systems. 
Previously, gE-deleted PR vaccines were found to be safe and efficacious for the control and eradication of PR [39]. The TK gene, as one of the first PRV genes, was responsible for virulence [40]. Accumulating evidence has shown that $\mathrm{TK}, \mathrm{gI}$, and $\mathrm{gE}$ genes are considered as major virulence determinants of PRV genome [41-44]. It has been reported that deleting the TK gene decreases virus replication in the nervous system and the ability to cause encephalitis [45,46]. In addition, the deletion of TK and gE/gI genes caused the reduction of virulence and attenuation of PRV, but did not affect the immunogenicity of PRV [18,47,48]. Interestingly, in this study, we demonstrate that the LD50 of $\mathrm{rGX} \Delta \mathrm{TK} / \mathrm{gE} / \mathrm{gI}$ was higher than $10^{5} \mathrm{TCID} 50$ in mice, whereas the LD50 of rGX $\Delta \mathrm{gE} / \mathrm{gI}$ in mice was (10 $\left.0^{3.68} \mathrm{TCID} 50\right)$ less than $10^{5} \mathrm{TCID} 50$, suggesting that $\mathrm{rGX} \Delta \mathrm{TK} / \mathrm{gE} / \mathrm{gI}$ may be safer than $\mathrm{rGX} \Delta \mathrm{gE} / \mathrm{gI}$ in mice. Notably, Wang et al. discovered that viral shedding was not showed in all pigs vaccinated with $\mathrm{rPRVTJ}-\Delta \mathrm{gE}$ [18]. Consistently, this study verified that no other clinical signs associated with PRV infection and viral shedding were observed in pigs vaccinated with $\mathrm{rGX} \Delta \mathrm{TK} / \mathrm{gE} / \mathrm{gI}$ and $\mathrm{rGX} \Delta \mathrm{gE} / \mathrm{gI}$ after challenge. However, after challenge, the pigs in $\mathrm{rGX} \Delta \mathrm{gE} / \mathrm{gI}$-vaccinated group had slight histopathological lesions compared with the pigs immunized with $\mathrm{rGX} \Delta \mathrm{TK} / \mathrm{gE} / \mathrm{gI}$. We speculate that virulence of $\mathrm{rGX} \Delta \mathrm{gE} / \mathrm{gI}$ may be stronger than that of $\mathrm{rGX} \Delta \mathrm{TK} / \mathrm{gE} / \mathrm{gI}$, leading to the histopathological lesions in the $\mathrm{rGX} \Delta \mathrm{gE} / \mathrm{gI}$-immunized group. It is important that a gene-deleted PRV can retain immunogenicity following the gene deletion [47]. In the current study, we demonstrate that the gE/gI- and gE/gI/TK-gene-deletions do not impair the immunogenicity of the virus in pigs. The PRV-specific cellular immune response and humoral immune response induced by $\mathrm{rGX} \Delta \mathrm{TK} / \mathrm{gE} / \mathrm{gI}$ were consistent with those caused by $\mathrm{rGX} \Delta \mathrm{gE} / \mathrm{gI}$ in pigs. Taken together, these results imply that $\mathrm{rGX} \Delta \mathrm{TK} / \mathrm{gE} / \mathrm{gI}$ may be a better candidate for the protection of PRV.

\section{Conclusions}

In conclusion, we combined CRISPR/Cas9 system and Cre/Lox system to generate gE/gI- and $\mathrm{gE} / \mathrm{gI} / \mathrm{TK}$-gene-deleted variants. The pathogenicity and immunogenicity were evaluated in susceptible animals. The findings indicate that the recombinant virus protects pigs against $\mathrm{PR}$, and $\mathrm{rGX} \Delta \mathrm{TK} / \mathrm{gE} / \mathrm{gI}$ may be a promising vaccine vector and better control of prevalent PR.

Author Contributions: Designed the experiments: P.Q., X.L. (Xiangmin Li), and H.C.; performed the experiments: J.L., K.F., Z.R., H.M., X.L. (Xinxin Li) and X.R.; analyzed the data: J.L., KF., and H.M.; wrote the paper: J.L.; proofed the manuscript: P.Q., X.L. (Xiangmin Li), and H.C. All authors have read and agreed to the published version of the manuscript.

Funding: This work was supported by the National Program on Key Research Project of China (2018YFD0500801, 2018YFD0500204), the Fundamental Research Funds for the Central Universities (2662016PY003), the Technology Base and Talents Special Program of Guangxi Province (2018AD09007), and Natural Science Foundation of Hubei Province (2019CFA010).

Acknowledgments: We are grateful to Gang Cao for his support to the technology.

Conflicts of Interest: The authors declare no conflict of interest.

\section{References}

1. Li, X.; Zhang, W.; Liu, Y.; Xie, J.; Hu, C.; Wang, X. Role of p53 in pseudorabies virus replication, pathogenicity, and host immune responses. Vet. Res. 2019, 50, 9. [CrossRef] [PubMed]

2. Pomeranz, L.E.; Reynolds, A.E.; Hengartner, C.J. Molecular biology of pseudorabies virus: Impact on neurovirology and veterinary medicine. Microbiol. Mol. Biol. Rev. 2005, 69, 462-500. [CrossRef] [PubMed]

3. Klupp, B.G.; Hengartner, C.J.; Mettenleiter, T.C.; Enquist, L.W. Complete, annotated sequence of the pseudorabies virus genome. J. Virol. 2004, 78, 424-440. [CrossRef]

4. $\quad$ An, T.Q.; Peng, J.M.; Tian, Z.J.; Zhao, H.Y.; Li, N.; Liu, Y.M.; Chen, J.Z.; Leng, C.L.; Sun, Y.; Chang, D.; et al. Pseudorabies virus variant in Bartha-K61-vaccinated pigs, China, 2012. Emerg. Infect. Dis. 2013, 19, 1749-1755. [CrossRef]

5. Wu, R.; Bai, C.; Sun, J.; Chang, S.; Zhang, X. Emergence of virulent pseudorabies virus infection in northern China. J. Vet. Sci. 2013, 14, 363-365. [CrossRef] 
6. van Oirschot, J.T. Diva vaccines that reduce virus transmission. J. Biotechnol. 1999, 73, 195-205. [CrossRef]

7. Moynagh, J. Aujeszky's disease and the European Community. Vet. Microbiol. 1997, 55, 159-166. [CrossRef]

8. Davidson, R.M. Control and eradication of animal diseases in New Zealand. N. Z. Vet. J. 2002, 50, 6-12. [CrossRef]

9. Sun, Y.; Luo, Y.; Wang, C.H.; Yuan, J.; Li, N.; Song, K.; Qiu, H.J. Control of swine pseudorabies in China: Opportunities and limitations. Vet. Microbiol. 2016, 183, 119-124. [CrossRef]

10. Mettenleiter, T.C. Immunobiology of pseudorabies (Aujeszky's disease). Vet. Immunol. Immunopathol. 1996, 54, 221-229. [CrossRef]

11. Dong, B.; Zarlenga, D.S.; Ren, X. An overview of live attenuated recombinant pseudorabies viruses for use as novel vaccines. J. Immunol. Res. 2014, 824630, 5. [CrossRef] [PubMed]

12. Kratchmarov, R.; Kramer, T.; Greco, T.M.; Taylor, M.P.; Ch'ng, T.H.; Cristea, I.M.; Enquist, L.W. Glycoproteins $\mathrm{gE}$ and $\mathrm{gI}$ are required for efficient KIF1A-dependent anterograde axonal transport of alphaherpesvirus particles in neurons. J. Virol. 2013, 87, 9431-9440. [CrossRef] [PubMed]

13. Olsen, L.M.; Ch'ng, T.H.; Card, J.P.; Enquist, L.W. Role of pseudorabies virus Us3 protein kinase during neuronal infection. J. Virol. 2006, 80, 6387-6398. [CrossRef] [PubMed]

14. Wang, G.S.; Du, Y.; Wu, J.Q.; Tian, F.L.; Yu, X.J.; Wang, J.B. Vaccine resistant pseudorabies virus causes mink infection in China. BMC Vet. Res. 2018, 14, 20. [CrossRef] [PubMed]

15. Ferrari, M.; Gualandi, G.L.; Corradi, A.; Monaci, C.; Romanelli, M.G.; Tosi, G.; Cantoni, A.M. Experimental infection of pigs with a thymidine kinase negative strain of pseudorabies virus. Comp. Immunol. Microbiol. Infect. Dis. 1998, 21, 291-303. [CrossRef]

16. van Oirschot, J.T.; Kaashoek, M.J.; Rijsewijk, F.A.; Stegeman, J.A. The use of marker vaccines in eradication of herpesviruses. J. Biotechnol. 1996, 44, 75-81. [CrossRef]

17. Vilnis, A.; Sussman, M.D.; Thacker, B.J.; Senn, M.; Maes, R.K. Vaccine genotype and route of administration affect pseudorabies field virus latency load after challenge. Vet. Microbiol. 1998, 62, 81-96. [CrossRef]

18. Wang, C.H.; Yuan, J.; Qin, H.Y.; Luo, Y.; Cong, X.; Li, Y.; Chen, J.; Li, S.; Sun, Y.; Qiu, H.J. A novel gE-deleted pseudorabies virus (PRV) provides rapid and complete protection from lethal challenge with the PRV variant emerging in Bartha-K61-vaccinated swine population in China. Vaccine 2014, 32, 3379-3385. [CrossRef]

19. Zhang, C.; Guo, L.; Jia, X.; Wang, T.; Wang, J.; Sun, Z.; Wang, L.; Li, X.; Tan, F.; Tian, K. Construction of a triple gene-deleted Chinese Pseudorabies virus variant and its efficacy study as a vaccine candidate on suckling piglets. Vaccine 2015, 33, 2432-2437. [CrossRef]

20. Gu, Z.; Dong, J.; Wang, J.; Hou, C.; Sun, H.; Yang, W.; Bai, J.; Jiang, P. A novel inactivated gE/gI deleted pseudorabies virus (PRV) vaccine completely protects pigs from an emerged variant PRV challenge. Virus Res. 2015, 195, 57-63. [CrossRef]

21. Savic, N.; Schwank, G. Advances in therapeutic CRISPR/Cas9 genome editing. Transl Res. 2016, 168, $15-21$. [CrossRef]

22. Cong, L.; Ran, F.A.; Cox, D.; Lin, S.; Barretto, R.; Habib, N.; Hsu, P.D.; Wu, X.; Jiang, W.; Marraffini, L.A.; et al. Multiplex genome engineering using CRISPR/Cas systems. Science 2013, 339, 819-823. [CrossRef]

23. Mali, P.; Yang, L.; Esvelt, K.M.; Aach, J.; Guell, M.; DiCarlo, J.E.; Norville, J.E.; Church, G.M. RNA-guided human genome engineering via Cas9. Science 2013, 339, 823-826. [CrossRef]

24. Liang, X.; Sun, L.; Yu, T.; Pan, Y.; Wang, D.; Hu, X.; Fu, Z.; He, Q.; Cao, G. A CRISPR/Cas9 and Cre/Lox system-based express vaccine development strategy against re-emerging Pseudorabies virus. Sci. Rep. 2016, 6, 19176. [CrossRef]

25. Van Duyne, G.D. Cre Recombinase. Microbiol. Spectr. 2015, 3, MDNA3-0014-2014. [CrossRef]

26. Ghosh, K.; Guo, F.; Van Duyne, G.D. Synapsis of loxP sites by Cre recombinase. J. Biol. Chem. 2007, 282, 24004-24016. [CrossRef]

27. Hamilton, D.L.; Abremski, K. Site-specific recombination by the bacteriophage P1 lox-Cre system. Cre-mediated synapsis of two lox sites. J. Mol. Biol. 1984, 178, 481-486. [CrossRef]

28. Grindley, N.D.; Whiteson, K.L.; Rice, P.A. Mechanisms of site-specific recombination. Annu. Rev. Biochem. 2006, 75, 567-605. [CrossRef]

29. Ye, C.; Zhang, Q.Z.; Tian, Z.J.; Zheng, H.; Zhao, K.; Liu, F.; Guo, J.C.; Tong, W.; Jiang, C.G.; Wang, S.J.; et al. Genomic characterization of emergent pseudorabies virus in China reveals marked sequence divergence: Evidence for the existence of two major genotypes. Virology 2015, 483, 32-43. [CrossRef] 
30. Smith, G.A.; Enquist, L.W. Construction and transposon mutagenesis in Escherichia coli of a full-length infectious clone of pseudorabies virus, an alphaherpesvirus. J. Virol. 1999, 73, 6405-6414. [CrossRef]

31. Sauer, B.; Whealy, M.; Robbins, A.; Enquist, L. Site-specific insertion of DNA into a pseudorabies virus vector. Proc. Natl. Acad. Sci. USA 1987, 84, 9108-9112. [CrossRef] [PubMed]

32. Yuan, L.; Wen, K.; Azevedo, M.S.; Gonzalez, A.M.; Zhang, W.; Saif, L.J. Virus-specific intestinal IFN-gamma producing $\mathrm{T}$ cell responses induced by human rotavirus infection and vaccines are correlated with protection against rotavirus diarrhea in gnotobiotic pigs. Vaccine 2008, 26, 3322-3331. [CrossRef] [PubMed]

33. Yuan, L.; Ward, L.A.; Rosen, B.I.; To, T.L.; Saif, L.J. Systematic and intestinal antibody-secreting cell responses and correlates of protective immunity to human rotavirus in a gnotobiotic pig model of disease. J. Virol. 1996, 70, 3075-3083. [CrossRef] [PubMed]

34. Meyer, A.G.; Wilke, C.O. Geometric Constraints Dominate the Antigenic Evolution of Influenza H3N2 Hemagglutinin. PLoS Pathog. 2015, 11. [CrossRef] [PubMed]

35. Williams, C.; Wells, J.; Klein, R.; Sylvester, T.; Sunenshine, R. Notes from the field: Outbreak of skin lesions among high school wrestlers-Arizona, 2014. Mmwr. Morb. Mortal. Wkly. Rep. 2015, 64, 559-560.

36. Lei, J.L.; Xia, S.L.; Wang, Y.; Du, M.; Xiang, G.T.; Cong, X.; Luo, Y.; Li, L.F.; Zhang, L.; Yu, J.; et al. Safety and immunogenicity of a $\mathrm{gE} / \mathrm{gI} / \mathrm{TK}$ gene-deleted pseudorabies virus variant expressing the $\mathrm{E} 2$ protein of classical swine fever virus in pigs. Immunol. Lett. 2016, 174, 63-71. [CrossRef]

37. Josefsberg, J.O.; Buckland, B. Vaccine process technology. Biotechnol. Bioeng. 2012, 109, 1443-1460. [CrossRef]

38. Abremski, K.; Hoess, R. Bacteriophage P1 site-specific recombination. Purification and properties of the Cre recombinase protein. J. Biol. Chem. 1984, 259, 1509-1514.

39. Freuling, C.M.; Muller, T.F.; Mettenleiter, T.C. Vaccines against pseudorabies virus (PrV). Vet. Microbiol. 2017, 206, 3-9. [CrossRef]

40. Kit, S.; Sheppard, M.; Ichimura, H.; Kit, M. Second-generation pseudorabies virus vaccine with deletions in thymidine kinase and glycoprotein genes. Am. J. Vet. Res. 1987, 48, 780-793.

41. Husak, P.J.; Kuo, T.; Enquist, L.W. Pseudorabies virus membrane proteins gI and gE facilitate anterograde spread of infection in projection-specific neurons in the rat. J. Virol. 2000, 74, 10975-10983. [CrossRef]

42. Jacobs, L.; Moonen-Leusen, B.M.; Bianchi, A.T.; Kimman, T.G. Glycoprotein gI of pseudorabies virus: Epitope-specific antibody response in mice and pigs. Acta Vet. Hung. 1994, 42, 347-351.

43. Mettenleiter, T.C.; Schreurs, C.; Zuckermann, F.; Ben-Porat, T. Role of pseudorabies virus glycoprotein gI in virus release from infected cells. J. Virol. 1987, 61, 2764-2769. [CrossRef]

44. Tirabassi, R.S.; Enquist, L.W. Role of the pseudorabies virus gI cytoplasmic domain in neuroinvasion, virulence, and posttranslational N-linked glycosylation. J. Virol. 2000, 74, 3505-3516. [CrossRef]

45. Ferrari, M.; Brack, A.; Romanelli, M.G.; Mettenleiter, T.C.; Corradi, A.; Dal Mas, N.; Losio, M.N.; Silini, R.; Pinoni, C.; Pratelli, A. A study of the ability of a TK-negative and gI/gE-negative pseudorabies virus (PRV) mutant inoculated by different routes to protect pigs against PRV infection. J. Vet. Med. BInfect. Dis. Vet. Public Health 2000, 47, 753-762. [CrossRef]

46. Ferrari, M.; Gualandi, G.L.; Corradi, A.; Monaci, C.; Romanelli, M.G.; Losio, M.N.; Cantoni, A.M.; Pratelli, A. The response of pigs inoculated with a thymidine kinase-negative (TK-) pseudorabies virus to challenge infection with virulent virus. Comp. Immunol. Microbiol. Infect. Dis. 2000, 23, 15-26. [CrossRef]

47. Cong, X.; Lei, J.L.; Xia, S.L.; Wang, Y.M.; Li, Y.; Li, S.; Luo, Y.; Sun, Y.; Qiu, H.J. Pathogenicity and immunogenicity of a $\mathrm{gE} / \mathrm{gI} / \mathrm{TK}$ gene-deleted pseudorabies virus variant in susceptible animals. Vet. Microbiol. 2016, 182, 170-177. [CrossRef]

48. Hong, Q.; Qian, P.; Li, X.M.; Yu, X.L.; Chen, H.C. A recombinant pseudorabies virus co-expressing capsid proteins precursor P1-2A of FMDV and VP2 protein of porcine parvovirus: A trivalent vaccine candidate. Biotechnol. Lett. 2007, 29, 1677-1683. [CrossRef]

(C) 2020 by the authors. Licensee MDPI, Basel, Switzerland. This article is an open access article distributed under the terms and conditions of the Creative Commons Attribution (CC BY) license (http://creativecommons.org/licenses/by/4.0/). 